\title{
Comparison of Rapid Antigen Test and Real-Time Reverse Transcriptase PCR for Diagnosing Novel Swine Influenza A (H1N1)
}

\author{
Aerin Kwon, Jae-Seok Kim, Han-Sung Kim, Wonkeun Song, \\ Ji-Young Park, Hyoun Chan Cho, Kyu Man Lee
}

\author{
Department of Laboratory Medicine, Hallym University College of Medicine, Seoul, Korea
}

Background: Novel swine influenza (H1N1) was first identified in Mexico in April 2009. Because of its high infectivity and worldwide distribution, a rapid and efficient screening test is necessary. Here we evaluated the usefulness of a rapid antigen test currently in use, compared to real-time RT-PCR (rRT-PCR) as a screening test for detection of novel swine influenza (H1N1).

Methods: A total of 1,228 patients who visited Hallym University Kangdong Sacred Heart Hospital with influenza-like illness between 14 August 2009 and 30 September 2009, and were tested by both rapid antigen and rRT-PCR tests, were enrolled in this study. Results: Sensitivity, specificity, predictive value of a positive test, and predictive value of a negative test for the rapid antigen test were $30.5 \%, 99.2 \%, 86.4 \%$ and $90.1 \%$, respectively. Fifty-one $(4.2 \%)$ patients were positive for both rapid antigen test and rRT$\mathrm{PCR}$, and $1,053(85.7 \%)$ were negative for both rap- id antigen test and rRT-PCR. A total of $124(10.1 \%)$ patients showed a discrepancy between the two tests. Among them, $116(9.4 \%)$ were only positive for rRT-PCR and $8(0.7 \%)$ were only positive for the rapid antigen test. The latter 8 patients all showed negative $\mathrm{H} 1 / \mathrm{M} 2$ results in $\mathrm{RRT}-\mathrm{PCR}$. There were significant differences in detection rates of the rapid antigen test between different $\mathrm{H} 1 \mathrm{Ct}$ (threshold cycle) interval groups and for different age groups ( $P$ $<0.05$ ).

Conclusion: Although the rapid antigen test is easy to perform and provides fast results, its limits as a screening test for detection of novel swine influenza (H1N1) due to its low sensitivity compared to rRTPCR need to be considered in practical situations. (Korean J Clin Microbiol 2010;13:109-113)

Key Words: Novel swine influenza, H1N1, Rapid antigen test, Real-time PCR, Sensitivity

\section{서 론}

인플루엔자 바이러스는 Orthomyxoviridae과에 속하는 단일 가닥 RNA 바이러스로 6 개 종이 있으며 그 중 $\mathrm{A}, \mathrm{B}$ 형이 주로 겨울철에 사람에게 호흡기 감염을 일으킨다[1,2]. 인플루엔자 바이러스 지질막에 위치한 hemagglutinin (HA), neuramidase (NA)와 M2 단백은 바이러스 복제에 중요한 역할을 하며 인플 루엔자 검사의 표적이 된다[3,4]. A형 인플루엔자 바이러스는 $\mathrm{HA}$ 와 $\mathrm{NA}$ 의 아미노산 구조에 지속적인 점돌연변이 즉, 소변이 (antigenic drift)가 일어나 매우 높은 유전적 다양성을 보이는 특징이 있다[3,5]. 이들 단백에 큰 항원변이가 일어나 기존에

Received 7 January, 2010, Revised 6 July, 2010

Accepted 20 July, 2010

Correspondence: Jae-Seok Kim, Department of Laboratory Medicine, Hallym University College of Medicine, Kangdong Sacred Heart Hospital, 445 Gil-dong, Gangdong-gu, Seoul 134-701, Korea. (Tel) 82-2-2224-2327, (Fax) 82-2-2224-2214, (E-mail) jaeseok@hallym. or.kr
존재하던 아형과 면역학적으로 완전히 다른, 새로운 HA나 NA 의 아형을 지닌 인플루엔자 바이러스 변종이 발생하여(대변이, antigenic shift) 인구집단을 감염시키면 대유행이 일어나게 된 다[5].

2009년 4월 멕시코에서 새로운 인플루엔자 A 바이러스가 분 리되어 신종인플루엔자(novel swine influenza A, H1N1)로 명 명되었다. 신종인플루엔자는 빠른 전파속도와 높은 전염성을 보여 2009년 6월 WHO는 대유행을 선포하였다[6-8].

신종인플루엔자의 전파를 감소시키고 환자에게 적절한 항바 이러스제를 사용하기 위해 신속한 선별검사가 필요하다[7,8]. 실시간 역전사 중합효소연쇄반응(real-time RT-PCR, rRT-PCR) 검사는 정확한 반면 고가이고 대부분의 1 차 의료기관에서 시행 하기 어렵다. 반면 계절인플루엔자 검사에 쓰이는 신속항원검 사는 검사방법이 간단하고 20 분 이내에 검사결과가 나오며 판 독이 쉽다[8,9]. 따라서 이 연구는 신종인플루엔자 진단을 위해 현재 사용하고 있는 신속항원검사와 rRT-PCR 검사를 비교하여 선별검사로서 신속항원검사의 유용성을 평가해보고자 하였다. 


\section{대상 및 방법}

\section{1. 대상}

2009년 8월 14일부터 9월 30일까지 한림대학교 강동성심병 원에 내원한 신종인플루엔자 의심환자 중 선별검사인 신속항 원검사와 확진검사인 rRT-PCR 검사를 모두 실시한 총 1,228 명 의 환자를 대상으로 하였다.

\section{2. 신속항원검사}

본 연구에서 사용된 신속항원검사(SD BIOLINE Influenza $\mathrm{Ag}$, Yongin, Korea)는 면역크로마토그래피방식을 이용하여 인 플루엔자 $\mathrm{A}, \mathrm{B}$ 각각에 특이적인 핵단백항원을 검출하며 계절 인플루엔자와 신종인플루엔자가 구별되지 않는다[10]. 동봉된 멸균면봉으로 비인두도말을 채취한 후 제조사의 지시대로 검 사를 시행하였다. 인플루엔자 A 반응선과 대조선 모두에 발색 반응이 관찰되면 인플루엔자 $\mathrm{A}$ 형 양성으로 판독하였다.

\section{3. rRT-PCR}

Flocked Swabs (Copan, Brescia, Italy)로 비인두도말을 채취 한 후 Universal Transport Medium (Copan)에 넣어 즉시 검사실 로 접수하고 $\mathrm{RNA}$ 추출 전까지 $4^{\circ} \mathrm{C}$ 에 보관하였다. QIAamp RNA Mini kit (QIAGEN, Valencia, CA, USA)와 QIAcube (QIAGEN) 기기를 이용하여 RNA를 추출하였다. 계절인플루 엔자와 신종인플루엔자에 공통적인 M2 유전자 및 신종인플루 엔자에 특이적인 $\mathrm{H1}$ 유전자를 사용하여 두 바이러스를 동시에 감별진단 가능한 one step rRT-PCR 키트인 Real-time Ready Influenza A/H1N1 Detection Set (Roche Diagnostics, Mannheim, Germany)시약을 이용하였다. 이 시약은 FDA에서 emergence use only로 허가되었다. M2 및 $\mathrm{H} 1$ 유전자 검출을 위해 각각 다른 튜브에서 다른 시발체-탐색자 혼합물을 사용하였다. RNA $5 \mathrm{uL}$, 시발체-탐색자 혼합물 $3 \mathrm{uL}$, 완충액 $4 \mathrm{uL}$, 효소 혼 합액 $0.4 \mathrm{uL}$, 증류수 $7.6 \mathrm{uL}$ 로 구성된 $\mathrm{PCR}$ 반응액으로 LightCycler 2.0 (Roche Diagnostics)과 LightCycler 480 II (Roche Diagnostics) 기기에서 PCR 반응을 실시하였다. 매 실

Table 1. Comparison of rapid antigen test and real-time RT-PCR for detection of novel swine influenza A (H1N1)

\begin{tabular}{lrcr}
\hline \multirow{2}{*}{$\begin{array}{l}\text { Real-time } \\
\text { RT-PCR }\end{array}$} & \multicolumn{3}{c}{ Rapid antigen test* } \\
\cline { 2 - 4 } & Positive & Negative & \multicolumn{1}{c}{ Total } \\
\hline Positive & $51(4.2 \%)$ & $116(9.4 \%)$ & $167(13.6 \%)$ \\
Negative & $8(0.7 \%)$ & $1,053(85.7 \%)$ & $1,061(86.4 \%)$ \\
Total & $59(4.8 \%)$ & $1,169(95.2 \%)$ & $1,228(100.0 \%)$ \\
\hline
\end{tabular}

*No. (\%) of patients.
험마다 키트에 포함되어 있는 양성대조물과 음성대조물을 포 함하여 검사하였다. $\mathrm{PCR}$ 반응은 $58^{\circ} \mathrm{C}$ 에서 8 분, $95^{\circ} \mathrm{C}$ 에서 30 초 반응 후 $95^{\circ} \mathrm{C}$ 에서 1 초, $60^{\circ} \mathrm{C}$ 에서 20 초, $72^{\circ} \mathrm{C}$ 에서 1 초 반응을 총 45 회 반복하고 최종적으로 $40^{\circ} \mathrm{C}$ 에서 30 초간 두었다. 모든 검사결과의 증폭곡선을 눈으로 직접 확인하였고, 판정이 불확 실한 경우 원검체로 RNA 추출과정부터 재검 또는 3차 재검을 실시하였다.

\section{4. 통계}

통계분석은 Excel version 2003 (Microsoft, Redmond, WA, USA)을 이용하여 실시하였다. rRT-PCR 검사에서 양성결과를 보였던 환자군 중 $\mathrm{Ct}$ (threshold cycle)값 및 연령대별로 나눈 군 간의 신속항원검사 양성률 비교를 위해 chi-square test를 실시 하였고, 유의수준은 0.05 로 하였다.

\section{결 과}

총 1,228명(남자 601명, 여자 627명)이 이번 연구에 포함되었 다. 평균연령은 20.4세(1개월 97세)였다. rRT-PCR 검사를 확 진검사로 하여 신속항원검사의 검사능을 평가하였다. 신속항 원검사의 민감도, 특이도, 양성검사 예측률(predictive value of a positive test), 음성검사 예측률(predictive value of a negative test) 및 검사효율성은 각각 $30.5 \%, 99.2 \%, 86.4 \%, 90.1 \%$, $89.9 \%$ 였다. 신속항원검사 및 rRT-PCR 검사결과는 Table 1과 같다. 총 1,104 명 $(89.9 \%)$ 에서 신속항원검사와 rRT-PCR 검사결 과가 일치하였고 나머지 124명(10.1\%)은 두 검사결과가 불일 치하였다. 신속항원검사에서만 양성반응을 보였던 환자 8 명 모 두 rRT-PCR 검사에서 H1/M2 음성이었다. rRT-PCR 검사의 H1 Ct값과 환자의 연령대에 따라 신속항원검사의 양성률이 통계

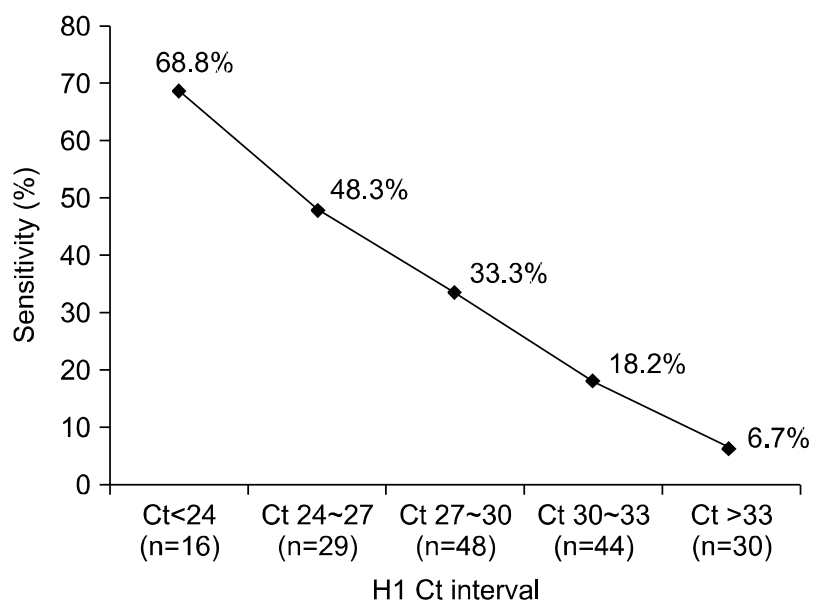

Fig. 1. Comparison of rapid antigen test sensitivity between different $\mathrm{H} 1 \mathrm{Ct}^{*}$ interval groups among novel swine influenza A (H1N1) patients confirmed by real-time RT-PCR. ${ }^{*} \mathrm{Ct}$, threshold cycle. 
Table 2. Comparison of rapid antigen test results between different age groups among novel swine influenza A (H1N1) patients confirmed by real-time RT-PCR

\begin{tabular}{lrrr}
\hline \multirow{2}{*}{$\begin{array}{c}\text { Age } \\
\text { (year) }\end{array}$} & \multicolumn{3}{c}{ Rapid antigen test* } \\
\cline { 2 - 4 } & \multicolumn{1}{c}{ Positive } & Negative & Total \\
\hline$<13$ & $20(44.4 \%)$ & $25(55.6 \%)$ & 45 \\
$13 \sim 29$ & $29(26.9 \%)$ & $79(73.1 \%)$ & 108 \\
$\geq 30$ & $2(14.3 \%)$ & $12(85.7 \%)$ & 14 \\
Total & $51(30.5 \%)$ & $116(69.5 \%)$ & 167 \\
\hline
\end{tabular}

*No. (\%) of patients.

적으로 유의한 차이를 보였다 $(P<0.05)$ (Fig. 1, Table 2).

\section{고 찰}

인플루엔자 바이러스는 흔히 겨울철에 발열, 기침, 콧물 등을 증상으로 하는 급성 호흡기 질환을 일으키며, 특히 $\mathrm{A}$ 형의 경우 지속적인 소변이와 대변이를 통해 유전자가 변화되어 효과적 인 백신개발이 어렵고 대유행이 발생하기도 한다[1,5,11]. 2009 년에 전세계적으로 범유행하고 있는 신종인플루엔자에 감염된 대부분의 환자는 가벼운 감기증세만 보이지만 입원치료가 필 요한 경우도 있고 일부는 중환자실치료를 받기도 한다[4]. 특히 면역력이 약한 영유아, 노인, 만성질환자, 임산부와 같은 고위 험군에서 높은 사망률을 보인다[1,4,12].

인플루엔자의 신속한 진단은 조기치료를 가능케 하여 임상 증상의 호전을 기대할 수 있고 바이러스의 전파, 입원치료기간, 불필요한 검사, 항바이러스제와 항생제의 남용, 합병증 및 사망 률을 감소시킬 수 있다[3,8,13,14]. 인플루엔자 바이러스의 진 단방법에는 신속항원검사, 바이러스 배양검사, rRT-PCR 검사, 다중 PCR 검사, 직접항원검사 등이 있다[9]. 고식적인 바이러 스 배양검사는 여전히 표준법으로 여겨지고 있으나 배양기간 이 2 14일로 길고 검사자의 숙련도를 요구하며 별도의 실험 실이 필요하다[13,14]. 또 다른 확진검사인 rRT-PCR 검사는 민 감도와 특이도가 높고 실시간으로 증폭상태를 확인 가능하며 반정량적으로 바이러스 농도를 예측할 수 있는 장점이 있다. 하지만 대부분의 1 차 의료기관에서 실행하기 어렵고 검사자의 숙련도가 역시 요구되며, 결과판정이 애매한 경우가 있어 전문 가의 판정이 필요하다[8,9,15]. 이에 비해 환자의 침상 또는 외 래 진료실에서 간편하게 검사하여 20 분 이내에 결과를 바로 알 수 있고 검사방법 및 판정이 매우 간단한 많은 종류의 인플루 엔자 현장검사 키트가 개발되어 널리 사용되고 있다[16]. 그러 나 신속항원검사는 특이도가 높은 반면 바이러스 배양검사와 rRT-PCR 검사에 비해 민감도가 떨어지는 단점이 있다 $[9,13,17]$.

계절인플루엔자 진단을 위한 여러 신속항원검사의 유용성을
평가한 논문들에서 신속항원검사의 민감도는 47 91\%로 다양 하게 보고되었다[9,11,13,14]. 이번 연구에 사용되었던 신속항 원검사의 민감도 역시 $55 \sim 88 \%$ 로 비슷하게 보고되었다 [18,19]. 신속항원검사의 민감도는 신종인플루엔자 진단을 위 해 사용되었을 때 이보다 더 낮게 조사되었는데, rRT-PCR과 비 교하여 Directigen EZ Flu A+B (Beckton, Dickinson and Company, Sparks, MD, USA), QuickVue Influenza A+B (Quidel Corporation, San Diego, CA, USA)와 BinaxNOW Influenza A\&B (Inverness Medical, Waltham, MA, USA)의 민 감도는 Vasoo 등[8]의 연구에서 각각 $46.7 \%, 53.3 \%, 38.3 \%$ 였고 $\mathrm{CDC}[15]$ 의 연구에서 각각 $49 \%, 69 \%, 40 \%$ 였다. 이번 연구에 사용되었던 신속항원검사는 이보다 더 낮은 $30.5 \%$ 의 민감도를 보였다.

신속항원검사의 민감도는 사용한 키트의 종류, 인플루엔자 바이러스의 아형, 검체의 종류, 검체운송 및 보관시간, 검체채 취시기, 환자의 연령, 검사자의 숙련도 등에 따라 다양하게 보 고되고 있다[3,8,10,11,13-15,17,18]. 사용한 키트의 종류와 인플 루엔자 바이러스의 아형을 제외한 나머지 요소는 모두 검체 내 바이러스 농도와 연관된 것들로서 바이러스 농도가 신속항원 검사의 민감도에 큰 영향을 미치는 것으로 생각된다. 이 연구 에서도 다른 문헌에서 보고된 바와 마찬가지로 $[8,15]$ 검체의 바 이러스 농도가 높을수록 신속항원검사의 양성률이 유의하게 높았다.

비인두흡인액이 비인두도말검체보다 바이러스양을 더 많이 포함하고 있어 신속항원검사에 더 좋은 검체이나 $[3,20]$ 검체채 취의 용이성으로 인해 이 연구에서는 모두 비인두도말검체를 사용하였다.

바이러스의 증식 및 분비는 증상발현 48시간째 최고조에 이 르고 그 이후에는 급감하기 때문에 검체를 채취하는 시점은 증 상이 발현되는 시점으로부터 3일 이내가 좋다[3]. 소아는 성인 보다 더 오랜 기간 바이러스를 분비하고 바이러스 농도의 감소 시기가 더 길어 증상 발현 5일 이후에 검체를 채취해도 유용하 다[3,15,21,22].

일반적으로 소아에서 성인보다 신속항원검사의 민감도가 더 우수한 것으로 알려져 있는데[13-15], 이번 연구에서도 13세 미 만에서 신속항원검사의 민감도가 $44.4 \%$ 로 가장 높았다(Table 2). 소아의 경우 면역체계가 불완전하여 바이러스 증식이 활발 히 일어나 분비량도 증가하고[10], 성인은 연령이 증가할수록 여러 인플루엔자 바이러스 아형에 대한 감염에 노출되기 때문 에 다양한 돌연변이에 대한 면역력이 축적되어 약하지만 어느 정도 보호작용을 해서 바이러스 증식이 억제될 가능성이 있다 [22].

따라서 증상 발현 2 3일 이내에 방문한 소아환자에서 숙련 된 검사자에 의해 검사를 실시하면 민감도가 더 높아질 것으로 생각되나 이에 대해서는 추가적인 연구가 필요하다. 
신속항원검사에서만 양성반응을 보였던 환자 8 명은 모두 발 열, 기침, 콧물, 가래 등 급성 호흡기질환증상을 보였으나 rRT-PCR 검사에서 H1/M2 음성이었고 동일한 검체로 재검을 실시해도 결과는 같았다. 검체 내에 과다한 점액질 또는 혈액 이 포함된 경우나 사용된 검체의 종류에 따라 신속항원검사에 서 위양성이 나올 수 있다는 보고가 있었다[23]. 염기서열분석 과 같은 다른 확진 방법을 통해 두 검사 간의 불일치 원인을 분석해야 할 것으로 생각된다.

이 연구에서 사용한 신속항원검사는 검사방법과 판정이 간 단하고 빠른 시간 내에 검사결과를 알 수 있으며 특이도가 높 은 장점이 있으나 민감도와 음성예측도가 낮아 신종인플루엔 자의 조기진단을 위한 검사로는 한계가 있을 것으로 생각된다.

\section{참 고 문 헌}

1. Kim SH, Huh JH, Bae SY, Kim JS, Yoon SY, Lim CS, et al. Epidemiology of respiratory viral infection in 2004-2006. Korean J Lab Med 2006;26:351-7.

2. Lee WG, Lee HK, Kim HJ, Chung JK, Lee EH, Moon HR. Evaluation of a rapid antigen test for detection of influenza virus. Korean J Clin Microbiol 2004;7:119-23.

3. Petric M, Comanor L, Petti CA. Role of the laboratory in diagnosis of influenza during seasonal epidemics and potential pandemics. J Infect Dis 2006;194(Suppl 2):S98-110.

4. Peiris JS, Poon LL, Guan Y. Emergence of a novel swine-origin influenza A virus (S-OIV) H1N1 virus in humans. J Clin Virol 2009;45:169-73.

5. Gatherer D. The 2009 H1N1 influenza outbreak in its historical context. J Clin Virol 2009;45:174-8.

6. World Health Organization. WHO web sites on disease outbreak news. Pandemic (H1N1) 2009 - update 71. http://www.who.int/ csr/don/2009_10_23/en [Online] (last visited on 17 October 2009).

7. Panning $\mathrm{M}$, Eickmann $\mathrm{M}$, Landt $\mathrm{O}$, Monazahian $\mathrm{M}$, Olschläger $\mathrm{S}$, Baumgarte $\mathrm{S}$, et al. Detection of influenza $\mathrm{A}(\mathrm{H} 1 \mathrm{~N} 1) \mathrm{v}$ virus by real-time RT-PCR. Euro Surveill 2009;14:pii: 19329.

8. Vasoo S, Stevens J, Singh K. Rapid antigen tests for diagnosis of pandemic (Swine) influenza A/H1N1. Clin Infect Dis 2009;49: 1090-3.

9. Rahman M, Vandermause MF, Kieke BA, Belongia EA. Performance of Binax NOW Flu A and B and direct fluorescent assay in comparison with a composite of viral culture or reverse transcription polymerase chain reaction for detection of influenza infection during the 2006 to 2007 season. Diagn Microbiol Infect Dis 2008;62:162-6.

10. Song SH and Kim EC. Rapid diagnosis of respiratory virus infection. J Lab Med Qual Assur 2007;29:207-10.

11. Kim JS, Choi HJ, Ahn YM, Hwang YO. Clinical usefulness of rapid antigen test on the diagnosis of influenza. Korean J Pediatr 2005;48:1348-53.

12. Chan KH, Lai ST, Poon LL, Guan Y, Yuen KY, Peiris JS. Analytical sensitivity of rapid influenza antigen detection tests for swine-origin influenza virus (H1N1). J Clin Virol 2009;45:205-7.

13. Cheng CK, Cowling BJ, Chan KH, Fang VJ, Seto WH, Yung R, et al. Factors affecting QuickVue Influenza $\mathrm{A}+\mathrm{B}$ rapid test performance in the community setting. Diagn Microbiol Infect Dis 2009;65:35-41.

14. Ruest A, Michaud S, Deslandes S, Frost EH. Comparison of the Directigen flu A+B test, the QuickVue influenza test, and clinical case definition to viral culture and reverse transcription-PCR for rapid diagnosis of influenza virus infection. J Clin Microbiol 2003;41:3487-93.

15. Centers for Disease Control and Prevention (CDC). Evaluation of rapid influenza diagnostic tests for detection of novel influenza A (H1N1) Virus - United States, 2009. MMWR Morb Mortal Wkly Rep 2009;58:826-9.

16. Kang JO, Kim EC, Lee KM, Lee NY, Lee CK. Surveillance for respiratory virus testing situation in Korea and epidemiology for the respiratory viruses detected in 5 university hospitals: report from virus study group. Korean J Clin Microbiol 2007;10:102-8.

17. Chan KH, Lam SY, Puthavathana P, Nguyen TD, Long HT, Pang $\mathrm{CM}$, et al. Comparative analytical sensitivities of six rapid influenza A antigen detection test kits for detection of influenza A subtypes H1N1, H3N2 and H5N1. J Clin Virol 2007;38:169-71.

18. Yoo Y, Sohn JW, Park DW, Kim JY, Shin HK, Lee Y, et al. Clinical evaluation of the SD Bioline influenza virus antigen test for rapid detection of influenza viruses $\mathrm{A}$ and $\mathrm{B}$ in children and adults during the influenza season. Clin Vaccine Immunol 2007;14:1050-2.

19. Mai LQ, Hien PT, Hang NL, Oh JS, Ha GW, Kwon JA, et al. Evaluation of two lateral-flow chromatographic membrane lmmunoassays for rapid detection of influenza virus in limited respiratory specimens. J Lab Med Qual Assur 2005;27:243-9.

20. Chan KH, Maldeis N, Pope W, Yup A, Ozinskas A, Gill J, et al. Evaluation of the directigen FluA+B test for rapid diagnosis of influenza virus type $\mathrm{A}$ and $\mathrm{B}$ infections. J Clin Microbiol 2002;40:1675-80.

21. World Health Organization. WHO recommendations on the use of rapid testing for influenza diagnosis. http://www.who.int/csr/ disease/avian_influenza/guidelines/RapidTestInfluenza_web.pdf (last visited on July 2005).

22. Steininger C, Kundi M, Aberle SW, Aberle JH, Popow-Kraupp T. Effectiveness of reverse transcription-PCR, virus isolation, and enzyme-linked immunosorbent assay for diagnosis of influenza A virus infection in different age groups. J Clin Microbiol 2002;40:2051-6

23. Ginocchio CC, Zhang F, Manji R, Arora S, Bornfreund M, Falk L, et al. Evaluation of multiple test methods for the detection of the novel 2009 influenza A (H1N1) during the New York City outbreak. J Clin Virol 2009;45:191-5. 
$=$ 국문초록=

\section{신종인플루엔자 검시에 사용되는 신속항원검사와 실시간 역전사 중합효소연쇄반응검사의 비교}

한림대학교 의과대학 진단검사의학교실

권애린, 김재석, 김한성, 송원근, 박지영, 조현찬, 이규만

배경: 2009년 4월 멕시코에서 새로운 인플루엔자 A (H1N1) 바이러스가 분리되어 신종인플루엔자로 명명되었다. 신종인 플루엔자는 전파속도가 빠르고 감염성이 높아 빠른 진단을 위해 신속한 선별검사가 필요하다. 이 연구는 신종인플루엔 자 진단을 위해 현재 사용하고 있는 신속항원검사와 실시간 역전사 중합효소연쇄반응(real-time RT-PCR, rRT-PCR) 검사 를 비교하여 선별검사로서 신속항원검사의 유용성을 평가해보고자 하였다.

방법: 2009년 8월 14일부터 2009년 9월 30일까지 한림대학교 강동성심병원에 내원한 신종인플루엔자 의심환자 중, 선별 검사인 신속항원검사와 확진검사인 rRT-PCR 검사를 모두 실시한 총 1,228 명의 환자를 대상으로 하였다.

결과: 신속항원검사의 민감도, 특이도, 양성검사 예측률(predictive value of a positive test), 음성검사 예측률(predictive value of a negative test)은 각각 $30.5 \%, 99.2 \%, 86.4 \%, 90.1 \%$ 였다. 신속항원검사와 rRT-PCR 검사에 모두 양성인 환자는 51 명 $(4.2 \%)$ 이었고 모두 음성인 환자는 1,053 명 $(85.7 \%)$ 이었다. 총 124 명 $(10.1 \%)$ 이 두 검사 간의 결과 불일치를 보였다. rRT-PCR 검사에서 양성을 보였으나 신속항원검사에서 음성을 보인 환자는 116 명(9.4\%)이었으며, 8 명 $(0.7 \%)$ 은 신속항원 검사에서만 양성반응을 보였다. 신속항원검사에서만 양성반응을 보였던 환자 8 명 모두 rRT-PCR 검사에서 H1/M2 음성이 었다. rRT-PCR 검사의 H1 Ct 값(threshold cycle) 및 환자의 연령대에 따라 신속항원검사의 양성률에 차이를 보였으며 이는 통계적으로 유의하였다 $(P<0.05)$.

결론: 신속항원검사는 검사방법이 간편하고 빠른 시간 내에 검사결과를 알 수 있는 장점이 있지만 rRT-PCR 검사에 비해 민감도가 낮으므로, 신종인플루엔자의 선별검사로는 한계가 있을 것으로 생각된다. [대한임상미생물학회지 2010; 13:109-113]

교신저자 : 김재석, 134-701, 서울시 강동구 길동 445

한림대학교 의과대학 강동성심병원 진단검사의학과

Tel: 02-2224-2327, Fax: 02-2224-2214

E-mail: jaeseok@hallym.or.kr 